\title{
EWOLUCJA TEORII EKONOMII ROZWOJU W XX WIEKU: OD KATEGORII WZROSTU GOSPODARCZEGO DO KONCEPCJ ZRÓWNOWAŻONEGO ROZWOJU
}

\section{Wprowadzenie}

Problematyka postępu w gospodarce była obecna co najmniej od momentu narodzin klasycznej ekonomii pod koniec XVIII w. Jednak przez długi czas rozumienie rozwoju ekonomicznego zawężano do kategorii wzrostu ilościowego, uwzględniającego zasadniczo jedynie czynniki gospodarcze. Dopiero osiągnięcia ekonomii rozwoju XX w. sprawiły, że w badaniach nad przemianami gospodarczymi zaczęto podkreślać znaczenie także czynników jakościowych o charakterze pozaekonomicznym - w dużej mierze związanych $\mathrm{z}$ szeroko rozumianym rozwojem społecznym. W związku z tym pojawiły się różne teorie rozwoju społeczno-gospodarczego.

Ich wartość poznawcza i aplikacyjna stanowi problem badawczy niniejszego artykułu. Głównym celem autora jest przedstawienie ewolucji teorii zaliczanych do ekonomii rozwoju XX w. i ich ocena. Autor stawia tezę, że w obliczu wciąż aktualnych kwestii rozwojowych odwołanie się do źródeł historycznych, ich właściwe odczytanie i zinterpretowanie pozwala formułować istotne wnioski dla teraźniejszości i wyznaczać trafniejsze cele na przyszłość. Stwarza też szansę, by uniknąć błędów w bieżącej polityce społeczno-gospodarczej. Właściwa orientacja teoretyczna jest niezbędna, by móc podejmować optymalne decyzje w procesie projektowania i wdrażania działań prorozwojowych na poziomie lokalnym, regionalnym, krajowym i globalnym.

Najlepszym źródłem wiedzy o poszczególnych teoriach wzrostu i rozwoju gospodarczego są oczywiście oryginalne dzieła poszczególnych autorów. Szczegółowe studium tekstów źródłowych nie jest jednak możliwe w ramach niniejszego artykułu. Zostanie tu dokonany jedynie wybiórczy przegląd, porównanie i ocena najważniejszych teorii. Zostaną wykorzystane dostępne opracowania z zakresu historii myśli ekonomicznej. Literatura obcojęzyczna jest w tym względzie znacznie bogatsza od rodzimej. Do anglojęzycznych lektur szczególnie godnych polecenia można zaliczyć 
dzieła następujących autorów: James M. Cypher, James L. Dietz'; Gerald M. Meier, James E. Rauch ${ }^{2}$; Gerald M. Meier, Joseph E. Stiglitz (redaktorzy) ${ }^{3}$; E. Wayne Nafziger ${ }^{4}$; Michael P. Todaro, Stephen C. Smith ${ }^{5}$. W polskiej literaturze przedmiotu należy wyróżnić monografie takich autorów, jak: Ryszard Bartkowiak ${ }^{6}$, Zofia Kozak ${ }^{7}$, Czesław Strzeszewski ${ }^{8}$, Jerzy Telep ${ }^{9}$. Na uwagę zasługują również opracowania zbiorowe pod redakcją: Anny Bąkiewicz i Urszuli Żuławskiej ${ }^{10}$, Jana L. Bednarczyka, Sławomira I. Bukowskiego i Wiesławy Przybylskiej-Kapuścińskiej ${ }^{11}$, Ryszarda Piaseckiego ${ }^{12}$, Katarzyny Żukrowskiej ${ }^{13}$. Spośród licznych artykułów poświęconych tej tematyce warto przede wszystkim sięgnąć do opracowania Anny Bąkiewicz i Urszuli Żuławskiej $^{14}$. Autor wykorzystał również własny tekst ${ }^{15}$.

\section{Elementy teorii wzrostu gospodarczego}

Prosta i zwięzła definicja wzrostu gospodarczego utożsamia go z przyrostem bogactwa wytworzonego w danym kraju w określonym czasie. Tenże przyrost wyrażany jest przeważnie za pomocą stopy zwrotu, to znaczy: ilorazu wartości produkcji w danym okresie do produkcji z okresu poprzedniego. Mierząc wzrost gospodarczy, najczęściej oblicza się produkcję uzyskaną w ciągu danego roku. Zasadniczo jako wskaźnik wartości produkcji przyjmuje się produkt krajowy brutto (PKB), gdyż stosunkowo łatwo można go wyliczyć. Ponadto jest on stosunkowo mało wrażliwy

1 The Process of Economic Development, Routledge, London 1997.

2 Leading Issues in Economic Development, $8^{\text {th }}$ ed., Oxford University Press, Oxford 2005.

${ }^{3}$ Frontiers of Economic Development: The Future in Perspective, Oxford University Press, New York 2001.

${ }^{4}$ Economic Development, $5^{\text {th }}$ ed., Cambridge University Press, Cambridge 2012.

${ }^{5}$ Economic Development, Pearson Addison Wesley, Boston 2009.

${ }^{6}$ Granice wzrostu gospodarczego a rozwój ekonomii: wybrane zagadnienia ekonomii neoklasycznej i ekonomii rozwoju, Oficyna Wydawnicza SGH, Warszawa 2005.

${ }^{7}$ Ekonomia zacofania i rozwoju, Oficyna Wydawnicza SGH, Warszawa 2001.

${ }^{8}$ Integralny rozwój gospodarczy, ODiSS, Warszawa 1976.

9 Elementy ekonomii rozwoju, Wydawnictwo Wyższej Szkoły Cła i Logistyki, Warszawa 2010.

${ }_{10}$ Rozwój $w$ dobie globalizacji, PWE, Warszawa 2010.

${ }_{11}$ Mechanizmy i źródła wzrostu gospodarczego. Polityka ekonomiczna a wzrost gospodarczy, CeDeWu Sp. z o.o., Warszawa 2008.

12 Ekonomia rozwoju, PWE, Warszawa 2007.

${ }^{13}$ Nauki ekonomiczno-społeczne i rozwój, Oficyna Wydawnicza SGH, Warszawa 2008.

${ }_{14}$ Od teorii wzrostu do ekonomii rozwoju, w: Rozwój w dobie globalizacji, red. A. Bąkiewicz, U. Żuławska, PWE, Warszawa 2010, s. 64-88.

${ }_{15}$ A. Zadroga, Współczesna ekonomia w poszukiwaniu paradygmatu rozwoju gospodarczo-społecznego, „Roczniki ekonomii i zarządzania” nr 4(40), 2012, s. 23-39. 
na subiektywne oceny tych, którzy dokonują jego wyznaczania ${ }^{16}$. Z kolei przez pojęcie teorii wzrostu przyjęło się rozumieć „formalne modele ekonomiczne, dotyczące ilościowego pomnażania dóbr i usług w gospodarkach rynkowych. Starają się one wyjaśnić wzrost - lub jego brak - w gospodarkach, których funkcjonowanie opiera się na mechanizmie rynkowym. Teorie te, podobnie jak wiele innych, podlegaja ewolucji i zmianom"17.

Chociaż teorie wzrostu gospodarczego są zjawiskiem współczesnym, pojęcie wzrostu i zainteresowanie nim sięga początków myśli ekonomicznej. Spośród osiągnięć klasyków ekonomii w kwestii teorii wzrostu gospodarczego warto przede wszystkim wspomnieć18:

- koncepcję źródeł dobrobytu Adama Smitha (1723-1790) ${ }^{19}$,

- model dwusektorowy i teorię kosztów komparatywnych Davida Ricardo $(1772-1823)^{20}$,

- prawo ludnościowe Thomasa Malthusa (1766-1834) ${ }^{21}$,

- teorię rozwoju gospodarczego Karola Marksa (1818-1883)22.

Natomiast do neoklasycznych teorii wzrostu należy zaliczyć m.in.:

- model wzrostu Harroda-Domara,

- egzogeniczny model wzrostu Roberta Solowa.

Pewne braki powyższych ujęć problematyki rozwojowej uzupełniają nowe teorie wzrostu endogenicznego.

Oczywiście nie sposób dokonać tu szczegółowego opisu poszczególnych teorii. W kontekście celów niniejszej pracy warto jednak poddać ocenie wybrane koncepcje, zwłaszcza pod kątem uwzględnianych przez nie przyczyn wzrostu.

Teoria wzrostu gospodarczego szkoły klasycznej angielskiej (Smith, Ricardo, Mill) największą wagę przywiązuje do dwóch czynników produkcji: pracy i kapitału, przy czym kapitał uznany jest za najbardziej istotny. Tym samym dane społeczeństwo osiąga postęp gospodarczy dzięki stałemu przyrostowi kapitału, osiąganemu głównie poprzez gromadzenie prywatnych oszczędności. Natomiast czynniki pozaekonomiczne teoria klasyczna traktuje jako uboczne (pomimo ich uwzględnienia).

16 J. Brémond, J.-F. Couet, M.-M. Salort, Kompendium wiedzy o ekonomii, tłum. K. Malaga, PWN, Warszawa 2006, s. 80.

17 A. Bąkiewicz, U. Żuławska, op.cit., s. 64.

18 Szerzej na ten temat piszą: A. Bąkiewicz, U. Żuławska, ibidem, s. 65-73.

${ }^{19}$ An Inquiry into the Nature and Causes of the Wealth of Nations, W. Strahan and T. Cadell, London 1776.

20 The Principles of Political Economy and Taxation, John Murray, London 1817.

${ }^{21}$ An Essay on the Principle of Population, J. Johnson, London 1798.

${ }_{22}$ Zur Kritik der politischen Ökonomie, Erschienen 1859 bei Franz Duncker, Berlin; Das Kapital. Kritik der politischenOekonomie, Hamburg 1867 [Kapitat - Krytyka ekonomii politycznej, tom pierwszy, księga I: Proces wytwarzania kapitał, KiW, Warszawa 1951]. 
Podobne stanowisko reprezentuje szkoła neoklasyczna anglo-amerykańska (m.in. Marshall), niektórzy przedstawiciele szkoły matematycznej oraz K. Menger z niemieckiej szkoły historycznej ${ }^{23}$.

W teorii neoklasycznej podstawowym modelem, na którym bazują wszystkie inne, stał się model zarysowany przez Roya F. Harroda (1900-1978) w artykule ogłoszonym w 1939 r. An Essay in DynamicTheory ${ }^{24}$, a następnie rozwinięty w jego monografii Towards a Dynamic Economics: Some Recent Developments of Economic Theory and Their Application to Policy ${ }^{25}$. Model ten został uzupełniony modelem skonstruowanym przez Evseya D. Domara (1914-1997) w 1946 r. ${ }^{26}$ i stał się, pod nazwą modelu Harroda-Domara, reprezentatywnym wzorcem neoklasycznej teorii wzrostu ${ }^{27}$.

Model powstał w celu wyjaśnienia warunków stabilnego wzrostu w krajach rozwiniętych. Na jego podstawie można sformułować dwa zasadnicze wnioski: 1) wzrost gospodarczy jest tym większy, im większą część dochodu narodowego przeznacza się na inwestycje oraz 2) im większa jest wydajność kapitału. Uogólniając, można stwierdzić, że barierą wzrostu gospodarczego są niedostateczne oszczędności. To oznacza, że w praktyce gospodarczej należy dążyć do zwiększenia stopy oszczędności, m.in. poprzez akumulację zewnętrzną (kredyty, pomoc zagraniczna). Tym samym teoria Harroda-Domara utwierdziła wielu ekonomistów w przekonaniu, że państwo powinno odgrywać aktywną rolę w sferze oszczędzania, aby zapewnić gwarantowaną stopę oszczędności. Patrząc szerzej, model ten stał się uzasadnieniem aktywnej roli państwa w generowaniu wzrostu gospodarczego ${ }^{28}$.

Jak zauważa Czesław Strzeszewski, ,zasadniczym brakiem neoklasycznych i wszystkich innych teorii wzrostu, które nie potrafiły się wyrwać z zaklętego kręgu mikrostatyki, jest analiza problemu wzrostu na podstawie zbyt małej liczby jego czynników". Ten problem „wywołuje szczególne trudności przy analizie sytuacji krajów zacofanych gospodarczo”. Stąd „należy sądzić, że właśnie problem wzrostu gospodarczego krajów zacofanych w rozwoju gospodarczym stał się przyczyną rozszerzania analizy szkoły neoklasycznej i jej kontynuatorów na większą liczbę rozpatrywanych czynników"29.

23 Cz. Strzeszewski, op.cit., s. 9-10.

24 „Economic Journal” Nr 3, 1939, s. 14-33.

25 Macmillan, London 1948.

26 W związku z tym Domar opublikował artykuł: Capital Expansion, Rate of Growth and Employment, „Econometrica” Nr 4, 1946, s. 137-147.

27 Cz. Strzeszewski, op.cit., s. 11-12. „Model Harroda-Domara był uzupełniany o kolejne czynniki warunkujące wzrost gospodarczy. Tego zadania podjął się m.in. R. Solow i pokazał zależności między wyposażeniem w czynniki produkcji i efektywnością ich wykorzystania a stopą wzrostu” (A. Bąkiewicz, U. Żuławska, op.cit., s. 70). Egzogeniczny model wzrostu R. Solow opisał w artykule: Contribution to the Theory of Economic Growth, „Quartely Journal of Economics” Nr 2, 1956.

28 A. Bąkiewicz, U. Żuławska, op.cit., s. 69-70.

29 Cz. Strzeszewski, op.cit., s. 12-13. 
W tradycyjnych teoriach wzrostu rozważania koncentrowały się wokół procesu wyrównywania się proporcji czynników produkcji w długim okresie. Proces ten prowadzi do równowagi i jest zjawiskiem tymczasowym. W warunkach braku działania czynników zewnętrznych (egzogenicznych) w długim okresie wszystkie gospodarki krajowe miały zmierzać do zerowej stopy wzrostu. Przyjęcie takiego założenia sprawiło, że teorie klasyczne i neoklasyczne nie dostarczyły odpowiedzi na pytanie o przyczyny zróżnicowania poziomu rozwoju gospodarczego na świecie. Reakcją na ten problem było pojawienie się nowych teorii wzrostu, które skoncentrowały się na endogenicznych czynnikach. Zainteresowano się bardziej sposobem organizacji produkcji niż proporcjami jej czynników. Według zwolenników tych teorii ${ }^{30}$ wzrost gospodarczy jest procesem następującym w efekcie działania postępu technologicznego i organizacyjnego osiąganego dzięki wprowadzanym innowacjom. Na podstawie tej teorii staje się zrozumiałe, dlaczego kapitał odpływa z krajów na niższym poziomie rozwoju, gdzie jego krańcowa wydajność powinna być większa. Otóż potencjalna produkcyjność kapitału nie jest osiągana w krajach słabo rozwiniętych, ponieważ ma tam miejsce niedorozwój kapitału ludzkiego i infrastruktury, czyli czynników komplementarnych wobec kapitału finansowego. Z kolei w krajach wysoko rozwiniętych dzięki inwestycjom w owe komplementarne czynniki produkcji bardzo realne jest uzyskiwanie korzyści zewnętrznych i to właśnie przyciąga kapitał ${ }^{31}$.

\section{Przejście do kategorii rozwoju społeczno-gospodarczego}

Z analiz historii myśli ekonomii można wysnuć wniosek, iż początkowo pojęcia wzrostu oraz rozwoju gospodarczego utożsamiano ze sobą. Dopiero stopniowo termin „Wzrost" zaczęto odnosić raczej do ilościowych zmian występujących w gospodarce, natomiast pojęcie "rozwoju” zaczęto stosować na oznaczenie przemian zarówno ilościowych, jak i jakościowych zachodzących w strukturach społeczno-gospodarczych ${ }^{32}$.

30 Za takich należy uznać: Josepha Schumpetera (1883-1950) oraz Walta Whitmana Rostowa (1916-2003). Główne dzieła Schumpetera to: Business Cycles. A Theoretical, Historical and Statistical Analysis of the Capitalist Process, McGraw-Hill Book Company, New York 1939 oraz The Theory of Economic Development: an Inquiry into Profits, Capital, Credit, Interest, and the Business Cycle, Transaction Books, New Brunswick, New Jersey 1934. Z kolei Rostow swój pogląd, że to rozwój innowacji jest głównym motorem wzrostu gospodarczego, zawarł w monografii The Process of Economic Growth, W.W. Norton, New York 1952, s. 12 i n., 15 i n. i 80.

${ }^{31}$ A. Bąkiewicz, U. Żuławska, op.cit., s. 72-73.

32 Zdaniem Zofii Dobrskiej w ewolucji pojęcia rozwój można wyróżnić trzy następujące podejścia do pojęcia rozwoju: 1) identyfikowanie rozwoju ze wzrostem rozmiarów produkcji, czyli ze wzrostem dochodu narodowego; 2) identyfikowanie rozwoju $\mathrm{z}$ tempem wzrostu dobrobytu społecznego jako najlepszym 
Według ekonomisty François Perroux „wzrost gospodarczy jest «trwałym zwiększaniem się produktu globalnego netto w kategoriach realnych, w jednym lub kilku długich okresach», natomiast «rozwój gospodarczy jest połączeniem zmian psychologicznych i społecznych ludności, które czynią ją zdolną do kumulowania i trwałego zwiększania swojego realnego produktu». Potrzeba takiego rozróżnienia wynika z chęci wyraźnego stwierdzenia, że wzrost produkcji jest tylko celem cząstkowym w stosunku do ogólniejszego celu, jakim jest rozwój. Rozwój gospodarczy obejmuje pojęcie wzrostu gospodarczego, lecz nie zawęża się do niego. Implikuje on, poza wzrostem gospodarczym, spełnienie wielu warunków, które pozwalają na kontynuację wzrostu gospodarczego w długim okresie. Na przykład kraj, który zwiększa swój PKB w danym roku wskutek wzrostu wydobycia ropy naftowej ze złóż własnych, może odnotować istotny wzrost gospodarczy. Kraj ten rozwija się jednak tylko wtedy, gdy równolegle ze wzrostem gospodarczym dokonują się pewne przekształcenia w naturze zatrudnienia, produkcji i w sposobach produkcji (kształcenie inżynierów, budowa fabryk, ...), które są warunkiem utrzymania wzrostu gospodarczego w długim okresie"33.

Takie zwracanie uwagi przez coraz większą liczbę ekonomistów na względną wartość samego tylko wzrostu gospodarczego doprowadziło w ewolucji myśli społeczno-ekonomicznej do postawienia niezwykle istotnego pytania, dotyczącego kosztów przeobrażeń ściśle gospodarczych. Przyczyniły się do tego m.in. doświadczenie wielu krajów, w których procesom rozwojowym towarzyszyły poważne wstrząsy i napięcia społeczne, wzrost bezwzględnego ubóstwa, dezintegracja struktur gospodarczych czy wreszcie zagrożenia ekologiczne. Właśnie to zwróciło uwagę badaczy na konieczność prowadzenia rachunku nie tylko zysków, ale i strat ${ }^{34}$.

Z całą pewnością należy zgodzić się ze stwierdzeniem, że wzrost gospodarczy nie jest synonimem samych tylko korzyści. Wywołuje on bowiem określone negatywne efekty ${ }^{35}$ :

- warunki osiągania wzrostu gospodarczego mogą wymagać wysokich kosztów społecznych, tj. np. wzrostu bezrobocia, rozszerzenia i pogłębienia ubóstwa;

- wzrost gospodarczy może prowadzić do pogłębienia nierówności społecznych, gdyż sam przyrost produkcji nie gwarantuje jeszcze wszystkim jednakowych możliwości dostępu do nowo wytworzonych bogactw;

wyznacznikiem rozwoju gospodarczego w okresach późniejszych; 3) identyfikowanie rozwoju nie tyle $\mathrm{z}$ osiągnięciem jakiegoś stanu wielkości realnych (dochodu, dobrobytu), ile z wykształceniem się określonych mechanizmów funkcjonowania systemu. Z. Dobrska, Pojęcie rozwoju gospodarczego - analiza wstępna, w: Rozwój w dobie globalizacji, red. A. Bąkiewicz, U. Żuławska, PWN, Warszawa 2010, s. 28-32.

33 J. Brémond, J.-F. Couet, M.-M. Salort, op.cit., s. 105.

${ }^{34}$ Z. Dobrska, Pojęcie rozwoju..., op.cit., s. 28.

35 J. Brémond, J.-F. Couet, M.-M. Salort, op.cit., s. 81-82. 
- wzrost gospodarczy wywiera destrukcyjny wpływ na środowisko naturalne w produkcji zużywa się zasoby, które nie są odtwarzalne (surowce, energia); zmiany w poziomie konsumpcji i związane z tym nagromadzenie odpadów zwielokrotniły źródła zanieczyszczeń środowiska;

- wzrostowi gospodarczemu przypisuje się również zmiany systemu wartości, a szczególnie odchodzenie od sprawiedliwości społecznej i solidarności międzyludzkiej na rzecz pogłębienia postaw opartych przede wszystkim na produktywności i zysku finansowym.

Współcześnie, głównie dzięki osiągnięciom ekonomii rozwoju - co zostanie szerzej opisane w kolejnym punkcie - ocena poziomu postępu jest dokonywana poprzez uwzględnienie wielorakich parametrów, przez co dość powszechnie przyjęło się używać kategorii rozwoju społeczno-gospodarczego. Jedna z lepszych definicji tego pojęcia określa go jako „proces pozytywnych zmian ilościowo-jakościowych, dzięki którym w sferze wszelakiej działalności gospodarczej, kulturowej i społecznej oraz stosunków społeczno-produkcyjnych i polityczno-ustrojowych zwiększają się i udoskonalają istniejące zjawiska a także powstają i rozwijają się nowe zjawiska. Zmiany te zachodzą w ujęciu czasowym i przestrzennym"36. Do istotnych czynników, które bierze się pod uwagę w analizach rozwoju społeczno-gospodarczego, zalicza się m.in.: „zasoby ludnościowe, wykształcenie, wielkość i strukturę spożycia, długość życia, podatność gospodarki na zakłócenia, w której uwzględnia się wskaźniki handlu zagranicznego, strukturę gospodarki i ludność, bogactwo narodu obejmujące kapitał naturalny, fizyczny, ludzki i społeczny"37.

\section{Narodziny i kształtowanie się ekonomii rozwoju w XX w.}

Mniej więcej w połowie XXw., gdy obserwowano narastające zróżnicowanie $\mathrm{w}$ bogactwie, a w związku $\mathrm{z}$ tym także i w poziomie życia $\mathrm{w}$ różnych regionach świata oraz gdy w wyniku dekolonizacji na mapie świata pojawiły się liczne nowe państwa poszukujące sposobu przyspieszenia wzrostu gospodarczego, zdano sobie sprawę, iż teorie wzrostu opisujące ten proces w krajach wysoko uprzemysłowionych mają jedynie ograniczone zastosowanie do procesów gospodarczych przebiegających w większości krajów całego globu. Doprowadziło to do pogłębienia refleksji

36 L. Kupiec, Jaki rozwój?, w: Rozwój regionalny a rozwój zrównoważony, red. A.F. Bocian, Wydawnictwo Uniwersytetu w Białymstoku, Białystok 2008, s. 22.

37 J. Telep, Elementy ekonomii rozwoju, Wydawnictwo Wyższej Szkoły Cła i Logistyki, Warszawa 2010, s. 8. 
ekonomistów w przedmiocie rozwoju społeczno-gospodarczego. W efekcie tego w latach 50. XX w. powstała nowa dyscyplina ekonomiczna - ekonomia rozwoju (development economics) $^{38}$.

Przedmiotem badań ekonomii rozwoju - jak stwierdza Zofia Kozak - ,jest analiza istoty i przyczyn masowego ubóstwa oraz czynników, kierunków i narzędzi pobudzania rozwoju krajów mniej rozwiniętych. Ekonomia rozwoju zajęła się także naukową analizą, doskonaleniem i upowszechnianiem strategii rozwoju opracowanych i stosowanych przez rządy i organizacje międzynarodowe w niektórych krajach rozwijających się" ${ }^{39}$. Natomiast zasadniczym celem ekonomii rozwoju jest budowanie teorii ukazujących możliwości bądź to wyjścia z zacofania gospodarczego niektórych krajów, bądź osiągnięcia przez inne państwa wyższego poziomu rozwoju ${ }^{40}$. Jerzy Telep podkreśla, że „ekonomistom rozwojowym chodzi [...] o taki charakter i organizację życia gospodarczego i społecznego, które zapewniłyby szybkie zmiany materialne całego społeczeństwa, tj. transfer owoców postępu ekonomicznego do warstw społecznych, które są biedne" ${ }^{\text {"41 }}$. Nie można jednak na tej podstawie wyciągać wniosku, że ekonomia rozwoju jest teorią ekonomiczną ludzi biednych ${ }^{42}$. Za takim stwierdzeniem stoi poważne uproszenie, jakoby „rozwój” odnosił się wyłącznie do gospodarek ,trzecioświatowych”, gdyż w stosunku do krajów wysoko uprzemysłowionych przyjmuje się założenie, że ich struktury gospodarcze są na tyle rozwinięte, iż pozwalają na ciągłe zwiększanie rozmiarów produkcji i konsumpcji. Skutki rewolucji naukowo-technicznej pokazują jednak, że również w tych krajach zachodzi nie tylko proces (mniej lub bardziej stabilnego) wzrostu gospodarczego, ale że ma tam miejsce także rozwój w sensie jakościowej zmiany strukturalnej ${ }^{43}$.

W latach 50. i 60. XX w. przedstawiciele ekonomii rozwoju tworzyli teorie, które dziś noszą nazwę „teorii pierwszej generacji”. Do najważniejszych z nich należą:

- teoria big push ${ }^{44}$, czyli teoria „wielkiego pchnięcia”, której twórcą jest Paul Narcyz Rosenstein-Rodan (1902-1985);

- teoria zrównoważonego wzrostu autorstwa Ragnara Nurksego (1907-1959) ${ }^{45}$;

38 A. Bąkiewicz, U. Żuławska, op.cit., s. 64; R. Piasecki, Od autorów, w: Ekonomia rozwoju, red. R. Piasecki, PWE, Warszawa 2007, s. 7.

39 Z. Kozak, Ekonomia zacofania i rozwoju, Oficyna Wydawnicza SGH, Warszawa 2001, s. 8.

${ }^{40}$ J. Telep, op.cit., s. 8; A. Zadroga, op.cit., s. 24.

${ }^{41}$ J. Telep, op.cit., s. 12-13.

42 Ibidem, s. 13.

${ }^{43}$ Z. Dobrska, Pojęcie rozwoju..., op.cit., s. 29.

${ }^{44}$ P.N. Rosenstein-Rodan, The Theory of the „Big Push”, w: Leading Issues in Economic Development, red. G.M. Meier, Oxford University Press, New York 1976. Istotę teorii „,wielkiego pchnięcia” w zwięzły sposób przedstawiają A. Bąkiewicz i U. Żuławska, op.cit., s. 74-75.

45 R. Nurkse, Trade and Development, w: Ragnar Nurkse (1907-2007): Classical Development Economics and its Relevance for Today, red. R. Kattel, J.A. Kregel, E.S. Reinert, Anthem Press, London, New York 2009 
- Strategy of Economic Development - teoria autorstwa Alberta Otto Hirschmanna (1915-2012) ${ }^{46}$, która stanowi krytykę koncepcji rozwijanych przez Rosenstein-Rodana i Nurskego;

- teoria wzrostu z nieograniczonymi zasobami pracy Arthura Williama Lewisa $(1915-1991)^{47}$;

- teoria stadiów wzrostu Walta Whitmana Rostowa (1916-2003) ${ }^{48}$.

Ponadto w tym początkowym okresie tworzenia dorobku ekonomii rozwoju, trwającym od przełomu lat 40. i 50. do połowy lat 70. XX w., dominowały - ogólnie rzecz biorąc - powiązane z keynesizmem strukturalne teorie rozwoju, a uzupełniały je nawiązujące do dorobku neoklasycznego modele wzrostu kumulatywnego, mające rodowód socjologiczny - opisowe teorie modernizacji, oraz radykalne teorie rozwoju społeczno-gospodarczego pochodzenia marksistowskiego ${ }^{49}$.

Odmienną grupę teorii - określaną jako druga generacja teorii rozwoju (lata 70. XX w.) - stanowi myśl gospodarcza przedstawicieli kilku kierunków (niezbyt spójnych $)^{50}$. Są to instytucjonaliści, m.in. Clarence Edwin Ayres (1891-1972), Gunnar Myrdal (1898-1987), Hernando de Soto (ur. 1941), oraz skupieni wokół jednego ośrodka (Komisja Ekonomiczna Narodów Zjednoczonych dla Ameryki Łacińskiej z siedzibą w Santiago de Chile) i nierzadko reprezentowani przez te same osoby strukturaliści i reprezentanci szkoły zależności, m.in. Raúl Prebisch (1901-1986),

[collection of all key works by Nurkse]. A. Bąkiewicz i U. Żuławska zauważają, że teoria Nurksego „ma dwa lub trzy aspekty, z których najbardziej chyba znanym jest pokazanie negatywnego sprzężenia zwrotnego w gospodarce, które późniejsi autorzy mieli nazwać błędnym kołem ubóstwa” (op.cit., s. 75). Szerzej na ten temat tej teorii: ibidem, s. 75-76.

46 Strategy of Economic Development, Yale University Press, New Haven, Connecticut (Oxford University Press, London) 1958. Jego głównym wkładem do ekonomii rozwoju jest „Zwrócenie uwagi na niemożność utrzymania równowagi w gospodarce, która dokonuje inwestycji zgodnie z teorią "wielkiego pchnięcia»". A. Bąkiewicz, U. Żuławska, op.cit., s. 77.

47 A.W. Lewis, Economic Development with Unlimited Supplies of Labor, „Manchester School of Economic and Social Studies” Vol. 22, Nr 2,1954. „Teoria A. Lewisa dała początek serii teorii, które zwracały uwage na dualność systemów gospodarczych w krajach gospodarczo mniej zaawansowanych. Dla A. Lewisa najistotniejszą cechą gospodarczą krajów mniej zaawansowanych było równoczesne funkcjonowanie sektora tradycyjnego, związanego głównie z rolnictwem, i sektora nowoczesnego, występującego głównie w przemyśle". A. Bąkiewicz, U. Żuławska, op.cit., s. 78.

48 The Stages of Economic Growth: A Non-Communist Manifesto, Cambridge University Press, Cambridge 1960. Teoria Rostowa próbuje w sposób uniwersalny zinterpretować historię gospodarczą wszystkich krajów, wszystkich społeczeństw świata, dzieląc historię gospodarczą na pięć stadiów wzrostu: 1) stadium społeczeństwa tradycyjnego (traditional society), 2) stadium tworzenia warunków wstępnych do startu (preconditions for take-off), 3) stadium startu do trwałego wzrostu (take-off), 4) stadium dochodzenia do dojrzałości (drive to maturity), 5) stadium masowej konsumpcji (age of high mass consumption). Rostow dowodzi, iż każde społeczeństwo musi przejść przez te stadia rozwoju.

49 J. Brémond, J.-F. Couet, M.-M. Salort, op.cit., s. 95-104; A. Zadroga, op.cit., s. 27. Zob. także A. Krawiec, Wzrost gospodarczy, w: Słownik społeczny, red. B. Szlachta, Wydawnictwo WAM, Kraków 2004, s. 1583-1587.

${ }^{50}$ Liczba publikacji reprezentantów tej grupy jest tak duża, że bardzo trudno dokonać syntezy ich poglądów. 
Juan F. Noyola Vázquez (1922-1962), Celso Monteiro Furtado (1920-2004), Osvaldo Sunkel (ur. 1929), Dudley Seers (1920-1983), Andre Gunder Frank (1929-2005).

Instytucjonaliścici ${ }^{51}$ zwrócili uwagę m.in. na to, że ważnymi czynnikami przeciwdziałającymi postępowi technologicznemu, który pozwala na efektywny wzrost gospodarczy w krajach tzw. Trzeciego Świata, są ograniczenia społeczne w pionowej ruchliwości ludzi i narzucone im wzorce zachowania. Takie poglądy głosi C.E. Ayres ${ }^{52}$. Bariery rozwoju widzieli również $\mathrm{w}$ wewnętrznych, ale także i międzynarodowych dysproporcjach w bogactwie i dochodach. Stąd - zdaniem G. Myrdala ${ }^{53}$ - konieczna jest zmiana w strukturze instytucji, którą może przeprowadzić jedynie państwo. Paradoks polega jednak na tym, że tam, gdzie potrzebna jest taka interwencja, zazwyczaj państwo jest na tyle słabe, że nie jest w stanie przeprowadzić stosownych zmian sprzyjających procesowi rozwoju. Na pewne konkretne formy instytucjonalnych niewydolności w krajach rozwijających się zwracał szczególną uwagę H. de Soto. $\mathrm{W}$ swoich pracach pisał m.in. o takich barierach rozwojowych, jak słaba ochrona praw własności czy nieudolność administracji ${ }^{54}$.

Z kolei strukturaliści podkreślali zwłaszcza aspekt dualności, a czasem nawet wieloukładowości gospodarek ${ }^{55}$ krajów będących na ścieżce rozwoju, co w praktyce oznacza, że w takiej sytuacji nie ma mowy o trwałym i szybkim postępie gospodarczym. Natomiast szkoła zależności, stanowiąca pewną modyfikację strukturalizmu, wiąże się głównie $\mathrm{z}$ wprowadzeniem do teorii ekonomii zainteresowanej problematyką międzynarodową pojęcia „centrum” i „peryferii”. Szkoła ta zwraca uwagę przede wszystkim na kwestię nieekwiwalentnego handlu międzynarodowego oraz problem deformacji struktur gospodarczych wynikający z niepoprawnych stosunków między państwami ${ }^{56}$.

W latach 80. nachylony społecznie paradygmat ekonomii rozwoju został wystawiony na ciężką próbę. Pojawiła się realna groźba załamania międzynarodowego systemu walutowego. Nastąpił także poważny kryzys zadłużeniowy, który wybuchł w 1982 r. i objął swym zasięgiem prawie wszystkie kraje Ameryki Łacińskiej oraz znaczną część krajów Afryki i środkowej Europy. Zdaniem wielu ówczesnych ekonomistów

51 A. Bąkiewicz, U. Żuławska, op.cit., s. 80; A. Zadroga, op.cit., s. 28.

52 Zob. W. Breit, W.P. Culbertson, Jr., Science and Ceremony: The Institutional Economics of C.E. Ayres, University of Texas Press, Austin 1976.

53 Zob. Asian Drama. An Inquiry into the Poverty Nations, Pantheon, New York 1968; Przeciw neddzy na świecie: zarys światowego programu walki z nędzą, tłum. W. Adamiecki, PIW, Warszawa 1975.

${ }^{54}$ Zob. Inny szlak: niewidzialna rewolucja $w$ Trzecim Świecie, tłum. S. Makowiecki, M. Wiśniewski, Polskie Towarzystwo Współpracy z Klubem Rzymskim, Warszawa 1991; Tajemnica kapitału: dlaczego kapitalizm triumfuje na Zachodzie a zawodzi gdzie indziej, tłum. Sz. Czarnik, Fijorr Publishing, Warszawa, Chicago 2002.

${ }^{55}$ Chodzi o współistnienie różnych systemów gospodarczych, które są tylko w niewielkim stopniu ze sobą powiązane.

56 A. Bąkiewicz, U. Żuławska, op.cit., s. 81; A. Zadroga, op.cit., s. 29. 
sytuacja zaistniałego kryzysu i pesymistyczna perspektywa na przyszłość dowodziły słabości strategii i polityk gospodarczych, które były realizowane w tych krajach. Tym samym poddano w wątpliwość dotychczasowy teoretyczny dorobek ekonomii rozwoju. Radykalnej zmianie uległa dotychczasowa polityka państw rozwiniętych (wierzycieli) wobec zadłużonych krajów rozwijających się. Polegała ona na narzuceniu obowiązku prowadzenia polityki stabilizacji i liberalizacji gospodarczej. Oznaczało to praktycznie postawienie wartości równowagi ekonomicznej ponad dotychczasowy proces stymulowania wzrostu i rozwoju gospodarczego.

Ponadto okazało się, że wzrostu gospodarczego nie można utożsamiać z rozwojem gospodarczym. Kryzysowi ekonomiczno-finansowemu towarzyszyły bowiem występujące na coraz większą skalę nastroje społecznego niezadowolenia. Ich źródło tkwiło w tym, że ciągle nie następował zadowalający przyrost nowych miejsce pracy, pogłębiało się za to rozwarstwienie dochodowe i poszerzały się obszary ubóstwa, krajom rozwijającym się zagrażała utrata kulturowej tożsamości, uwidaczniało się coraz większe uzależnienie w międzynarodowy stosunkach gospodarczych. W tym kontekście w połowie lat 80 . wielu ekonomistów ponownie zainteresowało się problematyką wzrostu i rozwoju gospodarczego, ponieważ zauważono, że nierówności społeczne nie sprzyjają rozwojowi gospodarczemu i że rozwój w związku z tym musi być postrzegany w szerokich kategoriach poprawy dobrobytu, standardów cywilizacyjnych i przestrzegania praw człowieka ${ }^{57}$.

Pod koniec lat 80., w obliczu zauważalnych niepowodzeń ekonomii rozwoju w postaci braku wyraźnego postępu gospodarczego większości krajów rozwijających się, nastąpił powrót do liberalnych koncepcji rozwoju. Swoich sił w naprawianiu gospodarek słabiej rozwiniętych zaczęli próbować neoliberałowie, skupieni przede wszystkim wokół Międzynarodowego Funduszu Walutowego i Banku Światowego. W wyniku tego doszło do wyraźnego ożywienia debaty między nimi, jako zwolennikami neoklasycznego podejścia do rozwoju gospodarczego (należał do nich m.in. Alan Krueger, Deepak Lal), a szeroko rozumianą i ogromnie zróżnicowaną „resztą," reprezentującą rozmaite nurty ekonomii rozwoju. Byli to m.in. strukturaliści, dependyści, neoinstytucjonaliści, ekonomiści z Komisji Brandta i wielu innych ${ }^{58}$. Generalnie rzecz ujmując, uwaga obu stron debaty nad rozwojem skupiała się na dwóch kwestiach: zwolennicy neoklasycyzmu akcentowali głównie system cen, zaś pozostali teoretycy twierdzili, że do uruchomienia procesów rozwoju potrzebna jest również interwencja państwa.

57 Ibidem, s. 29-31; R. Piasecki, Ewolucja teorii rozwoju gospodarczego, w: Ekonomia rozwoju, red. R. Piasecki, PWE, Warszawa 2007, s. 19.

58 A. Bąkiewicz, U. Żuławska, op.cit., s. 83; R. Piasecki, Ewolucja teorii..., op.cit., s. 20; A. Zadroga, op.cit., s. 31. 
Na gruncie rozważań neoklasycznych wypracowano doktrynę ekonomiczną, którą przyjęło się określać mianem „konsensusu waszyngtońskiego”. Doktryna ta została przedstawiona w roku 1990 przez Johna Wiliamsona (ur. 1937) ${ }^{59}$. Początkowo obejmowała zalecenia dla krajów Ameryki Łacińskiej, by z czasem stać się doktryną powszechnie obowiązującą w stosunku do krajów gospodarczo mniej zaawansowanych ${ }^{60}$.

Idee przewodnie konsensusu waszyngtońskiego streszczają się w postaci dziesięciu następujących zaleceń: „1) zrównoważony budżet państwa; 2) priorytet dla wydatków rządowych na edukację i opiekę zdrowotną oraz infrastrukturę; 3) reforma systemów podatkowych i wysoka ściągalność podatków; 4) utrzymanie pozytywnej, ale umiarkowanej realnej stopy procentowej; 5) jednolite kursy walutowe, zapewniające opłacalność eksportu i równowagę rachunku bieżącego bilansu płatniczego; 6) gwarancje dla własności prywatnej; 7) daleko posunięta deregulacja gospodarek; 8) liberalizacja handlu zagranicznego, zwłaszcza importu; 9) prywatyzacja majątku produkcyjnego w celu lepszego jego wykorzystania; 10) liberalizacja napływu bezpośrednich inwestycji zagranicznych" ${ }^{61}$.

Polityka gospodarcza prowadzona na podstawie tych zaleceń nie doprowadziła jednak do jakichś znaczących osiągnięć. Jak zauważa Piasecki, „do specyficznych cech blokujących wykorzystanie mechanizmów neoklasycznych zaliczano przede wszystkim: dualną strukturę społeczno-gospodarczą (w tym ostry podział na sektor nowoczesny i tradycyjny); dominację sektora tradycyjnego ze znacznym udziałem gospodarki naturalnej (np. 50\% sektora rolnego), a także brak infrastruktury rynkowej (np. instytucji finansowych) oraz rynku w wielu obszarach gospodarki; duży sektor nieformalny, sprawiający, że nie można zakładać pełnego zatrudnienia; dominację w gospodarce firm rodzinnych lub państwowych (w końcu lat 80.), a nie przedsiębiorstw kapitalistycznych; na ogół inną reakcję popytu i podaży na zmiany cen (są mało elastyczne), a także małą substytucyjność czynników produkcji itd.; występowanie w gospodarce tych krajów wielu zjawisk nietypowych (m.in. odwrotnie nachylona krzywa podaży)"62. Między innymi z tych powodów pod koniec lat 90. XX w. nastąpił powrót do głównych idei ekonomii rozwoju. Mimo to faktem jest, że od czasu konsensusu waszyngtońskiego, propagowanego przez Bank Światowy i Międzynarodowy Fundusz Walutowy, rozumienie mechanizmów rozwoju

${ }_{59}$ Zob. m.in. J. Williamson, Development and the “Washington Consensus”, „World Development” Vol. 21, 1993, s. 1239-1336.

${ }^{60}$ A. Bąkiewicz, U. Żuławska, op.cit., s. 83.

${ }^{61}$ Zob. J. Williamson, Latin American Adjustment: How Much Has Happened?, „IMF Working Paper” Nr 52, 1990; cyt. za: A. Bąkiewicz, U. Żuławska, op.cit., s. 83.

${ }^{62}$ R. Piasecki, Ewolucja teorii..., op.cit., s. 22. 
gospodarczego uległo znacznemu pogłębieniu. Przedmiotem analizy stały się takie czynniki, jak: kapitał fizyczny, kapitał ludzki, kształtowanie cen, a także geografia, instytucje i kultura ${ }^{63}$.

Od połowy lat 90. XX w. nastąpiło nowe spojrzenie na ekonomię rozwoju, które spowodowane było krytyką polityki gospodarczej prowadzonej w duchu założeń Banku Światowego i Międzynarodowego Funduszu Walutowego, a także takimi zjawiskami, jak przyspieszenie procesów globalizacyjnych oraz seria kryzysów finansowych w nowo uprzemysłowionych krajach azjatyckich i w niektórych państwach Ameryki Łacińskiej. Jedną z nowych propozycji było podejście uzyskane w ramach tzw. konsensusu z Santiago, wypracowanego na szczycie państw Ameryk w Santiago de Chile w 1998 r. Ów konsensus przede wszystkim przywracał znaczenie państwu jako podmiotowi, który jest w stanie korygować niedoskonałości rynku ${ }^{64}$.

Poza tym tacy wybitni ekonomiści jak Joseph Eugene Stiglitz (ur. 1943) czy Jeffrey Sachs (ur. 1954) zaczęli zwracać uwagę na to, by strategie rozwoju dostosowywać do specyfiki gospodarek poszczególnych - ekonomicznie mniej zaawansowanych krajów. Jednocześnie jednak państwa te muszą uwzględniać wszystkie konsekwencje gospodarcze, wynikające dla nich z rozwoju rynku globalnego ${ }^{65}$. Ponadto podkreślono konieczność systemowego traktowania tych gospodarek oraz szerokiego uwzględniania pozaekonomicznych uwarunkowań rozwoju ${ }^{66}$.

W tym okresie w ekonomii rozwoju na nowo rozgorzały dyskusje nad teoriami wzrostu. Poszukiwano nowych czynników mogących mieć znaczenie dla postępu gospodarczo-społecznego, i to nie tylko w gospodarkach mniej zaawansowanych, ale także w krajach o rozwiniętych gospodarkach rynkowych. W kręgu tych poszukiwań znalazły się m.in. odniesienia do wartości ekologicznych (dyskusja nad granicami wzrostu) czy też próby docenienia roli instytucji w rozwoju. W kontekście przemian społeczno-gospodarczych, dokonujących się zwłaszcza w krajach Europy Środkowowschodniej, na pograniczu ekonomii rozwoju pojawiło się zapotrzebowanie na teorię transformacji67.

63 Ibidem, s. 24.

64 A. Bąkiewicz, U. Żuławska, op.cit., s. 83; A. Zadroga, op.cit., s. 33.

65 G.M. Meier, J.E. Stiglitz, op.cit.; J.E. Stiglitz, Wizja sprawiedliwej globalizacji: propozycje usprawnień, tłum. A. Szeworski, Wydawnictwo Naukowe PWN, Warszawa 2007.

66 J. Sachs, Koniec z nędzą: zadanie dla naszego pokolenia, tłum. Z. Wiankowska-Ładyka, Wydawnictwo Naukowe PWN, Warszawa 2006. Podobne poglądy prezentuje G.W. Kołodko, Wędrujący świat, Prószyński i S-ka, Warszawa 2008.

67 A. Bąkiewicz, U. Żuławska, op.cit., s. 84. 


\section{Wnioski}

Zróżnicowanie stosunków społecznych, gospodarczych, kulturalnych, historycznych rozwoju poszczególnych państw i regionów świata decyduje o trudności opracowania uniwersalnej teorii wzrostu. Analizując rozłożenie akcentów w kwestii kluczowych czynników wzrostu gospodarczego w poszczególnych teoriach, należy stwierdzić, że teorie te koncentrowały się na wzroście zagregowanych wielkości ekonomicznych, tj.: dochód narodowy, produkcja, oszczędności, inwestycje, konsumpcja. Opierały się one na modelach gospodarki, w których eksponowano różne elementy. Na przykład model Harroda-Domara akcentował oszczędności i inwestycje (tj. kapitał). Inaczej ujmował to model Lewisa (model gospodarki o nadwyżce siły roboczej), który uwzględniał: płace, przeciętną wydajność pracy, bezrobocie i niepełne zatrudnienie $\mathrm{w}$ dwóch sektorach gospodarki (sektorze gospodarki naturalnej i sektorze nowoczesnym) oraz relacje ekonomiczne obu sektorów w procesie migracji, urbanizacji i wzrostu gospodarczego.

Dla teoretyków o poglądach keynesowskich i marksistowskich w patrzeniu na rozwój gospodarczy najważniejszym celem były wyższe dochody, które osiąga się dzięki inwestycjom generującym tenże dochód. Natomiast neoklasycy twierdzili, że jest możliwy wzrost stopniowy i stały, harmonijny i samonapędzający się - korzystny dla wszystkich grup społecznych w długim okresie. Duży nacisk kładli oni na sektor rolniczy i finansowy, a podstawowe czynniki wzrostu gospodarczego upatrywali w poprawie jakości siły roboczej i w zmianie struktury gospodarki, co miało się dokonać dzięki przesunięciu środków ze sfery o niższej produktywności do sfery o wyższej produktywności.

W ocenie Zofii Dobrskiej główne tezy teorii ekonomii rozwoju pierwszej generacji sprowadzić można do dwóch twierdzeń głoszących, że „warunkiem wstępnym i prawie wystarczającym rozwoju jest akumulacja kapitału; część akumulacji musi przyjść z zewnątrz: jako pomoc, także jako inwestycje zagraniczne"68. Natomiast jeśli chodzi o teorie drugiej generacji i późniejsze koncepcje, Jerzy Telep stwierdza, że „ekonomia rozwoju tego okresu stawiała cele społeczne na równi z celami ekonomicznymi, uwzględniając dobro przeciętnego człowieka, zwłaszcza grup społecznych ekonomicznie upośledzonych z jednoczesnym utrzymaniem zasad mikro- i makroefektywności gospodarczej. Strategiami tymi były: strategia potrzeb podstawowych,

68 Z. Dobrska, Zagadnienia gospodarcze krajów rozwijających się, [niepublikowane wykłady, Podyplomowe Studia Wiedzy o KRS - Instytut Krajów Rozwijających się - WGiSR UW], Warszawa 1994; cyt. za: A. Bąkiewicz, U. Żuławska, op.cit., s. 82. 
strategia walki z nędzą, strategia tworzenia nowych miejsc pracy, strategia redystrybucji dochodu narodowego, strategia oparcia na własnych siłach, rozwój oddolny"69.

Analizując proces kształtowania się ekonomii rozwoju, w tym czasowy okres niepowodzeń we wdrażaniu jej założeń teoretycznych, należy stwierdzić, że początkowo - podobnie jak było to w przypadku teorii wzrostu gospodarczego - przedmiot swoich badań ograniczała zasadniczo do czynników ekonomicznych. Tymczasem powinna ona objąć cały kompleks czynników rozwojowych zarówno ekonomicznych, jak i pozaekonomicznych.

Podsumowując dorobek ekonomii rozwoju XX w., można zauważyć, iż w tym czasie szczególnie podkreślono następujące kwestie:

- wzrost gospodarczy nie zawsze jest tożsamy z rozwojem,

- konieczne jest uwzględnianie społecznych uwarunkowań rozwoju gospodarczego,

- niezwykle istotną kwestią jest poszukiwanie rozwiązania problemu podziału dochodów.

Ostatecznie należy też stwierdzić, że obietnice teorii ekonomicznych rozwijających się do współczesności były dość atrakcyjne. Trzeba jednak też zauważyć, że nadal główne problemy ludzkości, tj. ubóstwo, bezrobocie, niestabilność gospodarczo-finansowa, pozostają nierozwiązane. Do tego katalogu wyzwań dołączono troskę o coraz mocniej zdewastowane środowisko naturalne. W tym kontekście pojawiły się próby określenia paradygmatu współczesnego rozwoju społeczno-gospodarczego.

\section{Literatura}

Bartkowiak R., Granice wzrostu gospodarczego a rozwój ekonomii: wybrane zagadnienia ekonomii neoklasycznej i ekonomii rozwoju, Oficyna Wydawnicza SGH, Warszawa 2005.

Bąkiewicz A., Żuławska U., Od teorii wzrostu do ekonomii rozwoju, w: Rozwój w dobie globalizacji, red. A. Bąkiewicz, U. Żuławska, PWE, Warszawa 2010, s. 64-88.

Breit W., Culbertson W.P., Jr., Science and Ceremony: The Institutional Economics of C.E. Ayres, University of Texas Press, Austin 1976.

Brémond J., Couet J.-F., Salort M.-M., Kompendium wiedzy o ekonomii, tłum. K. Malaga, PWN, Warszawa 2006.

Cypher J.M., Dietz J.L., The Process of Economic Development, Routledge, London 1997.

Dobrska Z., Pojęcie rozwoju gospodarczego - analiza wstępna, w: Rozwój w dobie globalizacji, red. A. Bąkiewicz, U. Żuławska, PWN, Warszawa 2010, s. 28-32.

${ }^{69}$ J. Telep, op.cit., s. 16. 
Dobrska Z., Zagadnienia gospodarcze krajów rozwijajacych się, niepublikowane wykłady, Podyplomowe Studia Wiedzy o KRS - Instytut Krajów Rozwijających się - WGiSR UW, Warszawa 1994.

Domar E.D., Capital Expansion, Rate of Growth and Employment, „Econometrica” Nr 4, 1946, s. 137-147.

Frontiers of Economic Development: The Future in Perspective, red. G.M. Meier, J.E. Stiglitz, Oxford University Press, New York 2001.

Harrod R.F., An Essay in Dynamic Theory, „Economic Journal” Nr 3, 1939, s. 14-33.

Harrod R.F., Towards a Dynamic Economics: Some Recent Developments of Economic Theory and Their Application to Policy, Macmillan, London 1948.

Hirschmann A.O., Strategy of Economic Development, Yale University Press, New Haven, Connecticut (Oxford University Press, London) 1958.

Kates W., Parris T.M., Leiserowitz A., What is Sustainable Development? Goals, Indicators, Values and Practice, „Environment: Science and Policy for Sustainable Development” Vol. 47, Issue 3, April 2005, s. 8-21.

Kołodko G.W., Wędrujący świat, Prószyński i S-ka, Warszawa 2008.

Kozak Z., Ekonomia zacofania i rozwoju, Oficyna Wydawnicza SGH, Warszawa 2001.

Krawiec A., Wzrost gospodarczy, w: Stownik społeczny, red. B. Szlachta, Wydawnictwo WAM, Kraków 2004, s. 1583-1587.

Kupiec L., Jaki rozwój?, w: Rozwój regionalny a rozwój zrównoważony, red. A.F. Bocian, Wydawnictwo Uniwersytetu w Białymstoku, Białystok 2008, s. 20-30.

Lewis A.W., Economic Development with Unlimited Supplies of Labor, „Manchester School of Economic and Social Studies" Vol. 22, Nr 2, 1954.

Malthus T., An Essay on the Principle of Population, J. Johnson, London 1798.

Marks K., Das Kapital. Kritik der politischenOekonomie, Meissner, Hamburg 1867.

Marks K., Kapitat - Krytyka ekonomii politycznej, tom pierwszy, księga I: Proces wytwarzania kapitału, KiW, Warszawa 1951.

Marks K., Zur Kritik der politischen Ökonomie, Erschienenbei Franz Duncker, Berlin1859.

Meier G.M., Rauch J.E., Leading Issues in Economic Development, $8^{\text {th }}$ ed., Oxford University Press, Oxford 2005.

Myrdal G., Asian Drama. An Inquiry into the Poverty Nations, Pantheon, New York 1968.

Myrdal G., Przeciw nędzy na świecie: zarys światowego programu walki z nędza, tłum. W. Adamiecki, PIW, Warszawa 1975.

Nafziger W.E., Economic Development, $5^{\text {th }}$ ed., Cambridge University Press, Cambridge 2012.

Nurkse R., Trade and Development, w: Ragnar Nurkse (1907-2007): Classical Development Economics and its Relevance for Today, red. R. Kattel, J.A. Kregel, E.S. Reinert, Anthem Press, London, New York 2009 [collection of all key works by Nurkse]. 
Piasecki R., Ewolucja teorii rozwoju gospodarczego, w: Ekonomia rozwoju, red. R. Piasecki, PWE, Warszawa 2007, s. 15-31.

Piasecki R., Od autorów, w: Ekonomia rozwoju, red. R. Piasecki, PWE, Warszawa 2007, s. 7-14.

Ricardo D., The Principles of Political Economy and Taxation, John Murray, London 1817.

Rosenstein-Rodan P.N., The Theory of the "Big Push", w: Leading Issues in Economic Development, red. G.M. Meier, Oxford University, New York 1976.

Rostow W.W., The Process of Economic Growth, W.W. Norton, New York 1952.

Rostow W.W., The Stages of Economic Growth: A Non-Communist Manifesto, Cambridge University Press, Cambridge 1960.

Sachs J., Koniec z nędzą: zadanie dla naszego pokolenia, tłum. Z. Wiankowska-Ładyka, Wydawnictwo Naukowe PWN, Warszawa 2006.

Schumpeter J., Business Cycles. A Theoretical, Historical and Statistical Analysis of the Capitalist Process, McGraw-Hill Book Company, New York 1939.

Schumpeter J., The Theory of Economic Development: an Inquiry into Profits, Capital, Credit, Interest, and the Business Cycle, Transaction Books, New Brunswick, New Jersey 1934.

Smith A., An Inquiry into the Nature and Causes of the Wealth of Nations, W. Strahan and T. Cadell, London 1776.

Solow R.M., Contribution to the Theory of Economic Growth, "Quartely Journal of Economics" Nr 2,1956.

Soto H., de, Inny szlak: niewidzialna rewolucja w Trzecim Świecie, tłum. S. Makowiecki, M. Wiśniewski, Polskie Towarzystwo Współpracy z Klubem Rzymskim, Warszawa 1991.

Soto H., de, Tajemnica kapitału: dlaczego kapitalizm triumfuje na Zachodzie a zawodzi gdzie indziej, tłum. Sz. Czarnik, Fijorr Publishing, Warszawa, Chicago 2002.

Stiglitz J.E., Wizja sprawiedliwej globalizacji: propozycje usprawnień, tłum. A. Szeworski, Wydawnictwo Naukowe PWN, Warszawa 2007.

Strzeszewski Cz., Integralny rozwój gospodarczy, ODiSS, Warszawa 1976.

Telep J., Elementy ekonomii rozwoju, Wydawnictwo Wyższej Szkoły Cła i Logistyki, Warszawa 2010.

Todaro M.P., Smith S.C., Economic Development, Pearson Addison Wesley, Boston 2009.

Wiliamson J., Latin American Adjustment: How Much Has Happened?, „IMF Working Paper” Nr 52, 1990.

Wiliamson J., Development and the "Washington Consensus”, „World Development” Vol. 21, 1993, s. 1239-1336.

Zadroga A., Współczesna ekonomia w poszukiwaniu paradygmatu rozwoju gospodarczo-społecznego, „Roczniki ekonomii i zarządzania” nr 4(40), 2012, s. 23-39. 


\section{Evolution of the theory of development economics in $20^{\text {th }}$ Century: from economic growth to sustainable development}

The article addresses the economic theories that have arisen on the basis of development economics of the $20^{\text {th }}$ century. The aim is to present the evolution of these concepts and to evaluate them. Historical, descriptive and comparative methods were used. The author argues that in face of current development issues a return to historical sources, combined with their proper reading and (re) interpretation, enables formulation of important conclusions for the present and setting more accurate targets for the future. Thanks to this reading and reinterpretation policy makers have a chance to avoid errors in managing the current socio-economic policy. The analysis led to the conclusion that (1) the understanding of economic development was at first narrowed to growth but with time has moved to (2) to the category of socio-economic development and in the $1950 \mathrm{~s}$ a new sub-discipline of economics - development economics - was developed. Its achievements helped to take into account in today's prevailing approaches the social determinants of economic growth, of which sustainable development is the most popular.

Keywords: history of economic thought, development economics, economic growth, socio-economic development, sustainable development

\section{Évolution de la théorie de l'économie du développement au XXème siècle: de la croissance économique au développement durable}

L'article traite des théories économiques qui ont surgi sur la base de l'économie du développement du XXème siècle. L'objectif est de présenter l'évolution de ces concepts et de les évaluer. Des méthodes historiques, descriptives et comparatives ont été utilisées. L'auteur fait valoir que, en face du développement actuel, un retour aux sources historiques, combiné à leur explication et (ré) interprétation correctes, permet la formulation de conclusions importantes actuelles et l'établissement d'objectifs plus précis pour l'avenir. Grâce à cette explication et réinterprétation, les décideurs ont une chance d'éviter des erreurs dans la gestion de la politique socio-économique actuelle. L'analyse a conduit à la conclusion que (1) la compréhension du développement économique a été, dans un premier temps, réduit à la croissance, mais, avec le temps, est passée (2) à la catégorie de développement socioéconomique et, dans les années 1950, une nouvelle sous-discipline de l'économie - l'économie du développement - s'est déployée. Ses réalisations ont aidé à prendre 
en compte, dans les approches appliquées aujourd'hui, les déterminants sociaux de la croissance économique, dont le développement durable est le plus populaire.

Mots-clés: histoire de la pensée économique, développement économique, croissance économique, développement socio-économique, développement durable

\section{Эволюция теории экономики развития в XX веке: от категории экономического роста к концепции устойчивого развития}

В статье рассматриваются экономические теории, возникшие на основе экономики развития в XX веке. Внимание уделяется их познавательному значению и возможностям применения. Цель работы заключается в представлении эволюции этих концепций и их оценке. Использовались историко-описательный и сравнительный методы. Исследовательский материал состоит из исторических источников и литературы по экономической мысли на польском и иностранных языках. Автор утверждает, что обращение к историческим источникам, их надлежащее чтение и интерпретация позволит сформулировать важные в настоящие время выводы и установить более точные цели на будущее. Это дает возможность избежать ошибок в социально-экономической политике. Проведенный анализ показал, что (1) первоначально понимание экономического развития было сужено к категории экономического роста. Со временем, (2) оно перешло к категории социально-экономического развития. В пятидесятых годах XX века (3) развилась новая субдисциплина экономики - экономика развития, что позволило включит социальные детерминанты экономического развития в доминирующие сегодня концепции. Самой популярной является концепция устойчивого развития.

Ключевые слова: история экономической мысли, экономика развития, экономический рост, социально-экономическое развитие, устойчивое развитие 